\title{
КОНЦЕПЦІЯ ФОРМУВАННЯ ЗМІШАНОЇ ЕКОНОМІКИ В УМОВАХ ФУНКЦІОНАЛЬНОЇ СОЦІАЛІЗАЦІЇ ВИРОБНИЦТВА
}

\author{
DOI: 10.32620/cher.2019.3.02
}

Постановка проблеми. Передумовою виникнення змішаної економіки в Україні є модель ііі соціально-економічного розвитку, що передбачає поєднання приватних й державних форм власності, планового й ринкового управління, проведення інституціональних та соціальних реформ задля прогресивного руху вперед. В процесі побудови змішаної економіки в Україні все більше поглиблюється розбіжність між запроектованою та реальною дійсністю. Тому виникає потреба у формування нової концепції розвитку змішаної економіки, виходячи із законів розвитку суспільства та економічного закону відповідності попиту існуючим пропозиціям. Метою дослідження означено обгрунтування системи відносин, що склалися у сучасній змішаній економіці під впливом історичних, технологічних, соціально-економічних світових та внутрішніх політичних процесів в Україні, та розробка концепції соціалізації виробництва, виходячи з умов функціонування економіки країни. Об 'єктом дослідження виступає економічна діяльність та процеси соціалізації, що відбуваються на виробничих підприємствах різних галузей та регіонів, котрі функціонують в сучасних формах розвитку змішаної економіки в Україні. Методологічною основою дослідження стали способи і принципи наукового пізнання, загальні та спеціальні методи, прийоми, що використані у процесі обгрунтування необхідності і доцільності соціалізації виробництва в умовах змішаної економіки, а саме: методи систематизації і узагальнення, що використані для аналізу існуючих підходів до формування напрямів соціалізації виробництва; індукції та дедукції - для обгрунтування прикладної цінності використання запропонованої концепції соціалізації виробництва в умовах існуючих форм змішаної економіки в Україні; аналогії - для оцінювання застосування світового досвіду до умов соціальноекономічного розвитку економіки, українського суспільства та їі громадян. Основною гіпотезою дослідження стало припущення, що застосування узагальненої концепції соціалізації змішаної економіки дозволить спрямувати увагу на забезпечення особистісних інтересів кожної людини - безпосереднього учасника будь-якого виробничого процесу. Виклад основного матеріалу дослідження. Доведено, що характерним для змішаної економіки є визначення пріоритетів, своєрідних орієнтирів, до яких слід відносити не лише національні пріоритети, але й сучасні особливості розвитку країни. Сьогоднішні глобалізаційні виклики актуалізують та орієнтують суспільство на вирішення проблематики етичних взаємовідносин, збереження життя людини, підтримки його добробуту та якості, самореалізації та самоорганізації кожного члена суспільства, розвиток різноманітних сфер соціуму, тобто на необхідності зосередитись на соціалізації змішаної економіки. Означено, що соціалізація - це процес формування соціальних якостей особистості, завдяки яким вона адаптується до суспільства та впливає на рівень розвитку усіх сфер його діяльності. Оригінальність та практичне значення дослідження. Запропонована узагальнена концепція та підходи до процесу соціалізації виробництва в умовах змішаної економіки мають оригінальність та практичну значимість і дозволяють змоделювати та уявити механізми соціалізації змішаної економіки, виходячи з тих соціально-економічних тенденцій та внутрішніх політичних процесів, що відбуваються в Україні; спрямувати увагу на забезпечення особистісних інтересів кожної людини, котра є безпосереднім учасником будь-якого виробничого процесу. Висновки. Соціалізація є основою міждисциплінарного дослідження; визначити доцільність розгляду та гармонізації взаємовідносин між людиною та суспільством; довести, що успішність процесу соціалізації залежить від реалізації і задоволенні інтересів і потреб суспільства, існуючих можливостей запровадження вибраних цінностей в змішану економіку та сприйняття цих орієнтирів українськім соціумом та кожним окремим громадянином.

\section{Ключові слова:}

змішана економіка, соціалізація виробництва, інтереси особистості, пріоритети, орієнтири, цінності, потреби суспільства.

1 Калінеску Тетяна Василівна, д-р екон. наук, професор, завідувач кафедри «Фінанси», Національний аерокосмічний університет ім. М.Є. Жуковського «Харківський авіаційний інститут», м. Харків, Україна.

Calinescu Tetyana, Doctor of Economic Sciences, Professor, Head of Finances Department National Aerospace University «Kharkiv Aviation Institute», Kharkiv, Ukraine.

ORCID ID: 0000-0003-4919-5788

e-mail: tetyana.calinescu@gmail.com 


\section{CONCEPTION OF FORMING THE MIXED ECONOMY IN CONDITIONS OF FUNCTIONAL SOCIALIZATION OF PRODUCTION}

Formulation of the problem. Pre-condition of origin the mixed economy in Ukraine is a model of its socio-economic development, which foresees combination of private and state patterns of ownership, planed and market management, realization of institutional and social reforms for the sake of progressive forward movement. In the process of construction the mixed economy in Ukraine are more deepens divergence between the projected and real reality. Therefore there is a requirement in forming of new conception of development the mixed economy, what going out the existent laws of society development and economic law of accordance the demand to existent suggestions. A research purpose is mark the ground of the system of relations which was folded in the modern mixed economy under act of historical, technological, socio-economic world and internal political processes in Ukraine, and development of conception the socialization of production, what coming from country conditions and operating of economy. The object of research there is economic activity and processes of socialization, which take place on the productive enterprises of different industries and regions which function in the modern forms of development of the mixed economy in Ukraine. Methodological basis of research became methods and principles of scientific cognition, general and special methods, receptions which are used in the process of ground the necessity and expediency of socialization the production in the conditions of the mixed economy, like as: methods of systematization and generalizations which are used for the analysis of existent approaches to forming the socialization directions of production; inductions and deductions? What are used for the ground of the applied value of the use offered conception of socialization production in the conditions of existent forms the mixed economy in Ukraine; analogies, what are used for the evaluation of application the world experience to the terms of socio-economic development of economy, Ukrainian society and its citizens. The basic hypothesis of research became supposition that application of the generalized conception of the mixed economy socialization will allow to point attention at providing of personality interests of everybody, who is direct participant of any productive process. Statement main material. It is well-proven that characteristic for the mixed economy is determination of priorities, original reference-points, should to include is not only national priorities, but also modern to the feature of development of country. The today's problems of globalization are actualized and oriented the society on the decision of questions of ethics mutual relations, maintenance of human life, support of his welfare and quality, self-realizations and self-organization every member of society, development of various spheres of society, and it is means, that need concentrated on socialization of the mixed economy. It is marked, that socialization there is a process of forming the social internals of personality, who is adapted oneself to society and influences on the level of development all spheres of its activity. And socialization must answer the economic and social necessities of society, to satisfy individual aspirations not only, but to arrive at collective reference-points, to explain to harmonious development, support of existent traditions and stimulate creation of the special citizen of society. The originality and practical value. The offered generalized conception and going near the process of socialization of production in the conditions of the mixed economy have originality and practical meaningfulness and allow to model and imagine the mechanisms of socialization of the mixed economy, what coming from those socio-economic tendencies and internal political processes which take place in Ukraine; to point attention at providing the personality interests of everybody which there is the direct participant of any productive process. The conducted research are allowed: to formulate a conclusion, that socialization is basis of between disciplinary research; to define expediency of consideration and harmonization of mutual relations between a human and society; to prove that success of socialization process is depend on realization satisfaction of interests requirements of society, existent possibilities input of the chosen values in the mixed economy and perception of these reference-points Ukrainian society and every separate citizen.

Key words:

the mixed economy, socialization of production, interests of personality, priorities, reference-points, values, necessities of society.

\section{КОНЦЕПЦИЯ ФОРМИРОВАНИЯ СМЕШАННОЙ ЭКОНОМИКИ В УСЛОВИЯХ ФУНКЦИОНАЛЬНОЙ СОЦИАЛИЗАЦИИ ПРОИЗВОДСТВА}

Постановка проблемы. Предпосылкой возникновения смешанной экономики в Украине является модель ее социально-экономического развития, которое предусматривает сочетание частных и государственных форм собственности, планового и рыночного управления, проведения институциональных и социальных реформ с целью прогрессивного движения вперед. В процессе построения смешанной экономики в Украине все более углубляется расхождение между задуманной и реальной действительностью. Поэтому возникает потребность в формирование новой концепции развития смешанной экономики, исходя из законов развития общества и экономического закона соответствия спроса существующим предложениям. Целью исследования является обоснование системы отношений, которые сложились в современной смешанной экономике под воздействием исторических, технологических, социальноэкономических мировых и внутренних политических процессов в Украине, и разработка концепции со- 
циализации производства, исходя из условий функционирования экономики страны. В качестве объекта исследования выступает экономическая деятельность и процессы социализации, которые происходят на производственных предприятиях разных отраслей и регионов, которые функционируют в современных формах развития смешанной экономики в Украине. Методологической основой исследования стали способы и принципы научного познания, общие и специальные методы, приемы, которые использованы в процессе обоснования необходимости и целесообразности социализации производства в условиях смешанной экономики, а именно: методы систематизации и обобщения, которые использованы для анализа существующих подходов до формирования направлений социализации производства; индукции и дедукции - для обоснования прикладной ценности использования предложенной концепции социализации производства в условиях существующих форм смешанной экономики в Украине; аналогии - для оценки применения мирового опыта к условиям социально-экономического развития экономики, украинского общества и ее граждан. Основной гипотезой исследования стало предположение, что применение обобщенной концепции социализации смешанной экономики позволит сосредочить внимание на обеспечении личностных интересов каждого человека - непосредственного участника любого производственного процесса. Изложение основного материала исследования. Доказано, что характерным для смешанной экономики является определение приоритетов, своеобразных ориентиров, к которым следует относить не только национальные приоритеты, но и современные особенности развития страны. Сегодняшние вызовы глобализаций актуализируют и ориентируют общество на решение проблематики этичных взаимоотношений, сохранения жизни человека, поддержки его благосостояния и качества, самореализации и самоорганизации каждого члена общества, развития разнообразных сфер социума, то есть на необходимости сосредоточиться на социализации смешанной экономики. Отмечено, что социализация - это процесс формирования социальных качеств личности, благодаря которым она адаптируется к обществу и влияет на уровень развития всех сфер его деятельности. А значит, социализация должна отвечать экономическим и социальным потребностям общества, удовлетворять не только индивидуальные стремления, но способствовать достижению коллективных ориентиров, мотивировать к гармоничному развитию, поддержке существующих традиций и стимулировать создание своего особенного гражданина общества. Оригинальность и практическое значение исследования. Предложенная обобщенная концепция и подходы к процессу социализации производства в условиях смешанной экономики имеют оригинальность, практическую значимость, позволяют смоделировать и представить механизмы социализации смешанной экономики, исходя из тех социально-экономических тенденций и внутренних политических процессов, которые происходят в Украине; направить внимание на обеспечение личных интересов каждого человека, который является непосредственным участником любого производственного процесса. Bblводbl. Социализация является основой междисциплинарного исследования; определить целесообразность рассмотрения и гармонизации взаимоотношений между человеком и обществом; доказать, что успешность процесса социализации зависит от реализации и удовлетворении интересов и потребностей общества, существующих возможностей ввода выбранных ценностей в смешанную экономику и восприятие этих ориентиров украинском социумом и каждым отдельным гражданином.

\section{Ключевые слова:}

смешанная экономика, социализация производства, интересы личности, приоритеты, ориентиры, ценности, потребности общества.

Постановка проблеми. Фундаментом будь-якої економіки виступають головні іiі елементи: продуктивні сили, соціальноекономічні відносини та механізм регулювання (управління). В залежності від специфіки розвитку окремих іiі елементів виокремлюються різні типи економік [1, с. 14 - 15]: натуральну, ринкову, командноадміністративну й змішану. Саме останній тип притаманний як вже досить розвинутим країнам, таким як Німеччина, Японія, Швеція, так і тим, що тільки-но завойовують певні позиції на міжнародній економічній арені, а саме В'єтнам, Індія, Китай та інші. Передумовою виникнення змішаної економіки є модель соціально-економічного розвитку, що передбачає поєднання приватних й держав- них форм власності, планового й ринкового управління, проведення інституціональних та соціальних реформ задля прогресивного руху вперед [2, с. 383 - 384]. Загалом переважають три варіанти моделей розвитку змішаної економіки: консервативний, ліберальний та соціально-реформістській. Саме останній варіант розвитку взято за основу в Україні і передбачає оптимальне поєднання децентралізації й централізації, планування і стихійного розвитку ринку, саморегулювання й державного управління, індивідуальних та колективних форм власності з метою соціалізації та збалансування економіки. Тому й не дивно виникнення нових моделей розвитку змішаної економіки, як: соціально-орієнтована економіка, модель соціально-економічного розвит- 
ку і т.п. Проте в процесі побудови змішаної економіки в Україні все більше поглиблюється розбіжність між запроектованою необхідністю, що відбиває виклики українського суспільства, та реальною дійсністю [3], що характеризує стан розвитку економіки та свідомості суспільства.

Останні дослідження, що проведені Світовим банком у 2018 році [4] показують, що біля 4\% населення України знаходять за визначеною офіціальною межею бідності, розрив доходів майже у 3,5 разів між багатими і найбіднішими прошаркам населення. У порівняні з 2008 роком тільки на 1 тис. доларів збільшився дохід на душу населення, а майже $40 \%$ населення, що відносять себе до середнього класу не можуть дозволити собі нічого, окрім витрачати гроші на продукти постійного споживання. Більше того, майже $70 \%$ населення вважають себе незадоволеними тими соціальними реформами, що відбувають в країні [5], а економічна ситуація, що $є$ наразі країні, $є$ більш реально незадовільною, ніж це можна побачити у офіціальній інформації. А значить ті темпи розвитку та позитивних змін у економіці України, що декларуються сьогодні новими доктринами розвитку $[6$, с. 36 , 37] та новим Кабінетом Міністрів, можуть бути набагато нижче передбачуваних, попри усі оптимістичні прогнози щодо соціально-економічних змін в країні [7] завдяки збільшення експорту, в тому числі до Свропейських країн у середньому на 5,0 - 6,5\% [8, с. 26] у порівнянні з 2013 роком, зростання заробітної плати по регіонам України у середньому на $19 \%$ - $69 \%$ у порівнянні 3 2014 роком [9, с. 32] та забезпечення економічного зростання продуктивною роботою нової української влади.

Тому виникає потреба щодо формування нової концепції розвитку змішаної економіки, виходячи із існуючих законів розвитку суспільства та економічного закону відповідності попиту існуючим пропозиціям.

Аналіз останніх досліджень і публікацій. Напрями розвитку змішаної економіки досліджуються вченими усіх напрямів економічної науки і практики. Досвід розвитку країн зі змішаними моделями економіки доводить, що ӥй властива низка пози- тивних рис, які забезпечують нову соціально-економічну якість життя суспільства, а саме [10]:

1) багатосекторність і поліформізм в економіці;

2) економічна свобода і рівність господарюючих суб'єктів;

3) соціальна орієнтація та розширення державного контролю та регулювання розміру державних витрат та долі державної власності;

4) рухливість у часі і просторі механізму господарювання;

5) гнучкість переходу одних форм власності в інші, що забезпечує цілісність економічної системи;

6) збалансування різнорідних економічних інтересів, котре забезпечує стабільність і стійкість розвитку економіки;

7) можливість нівелювати вплив на економіку країни світових фінансових та криз.

Виходячи 3 вище наведеного більшої актуальності, 3 точки зору їх соціалізації, набувають такі функції державного управління в Україні як забезпечення $[10 ; 11$, с. 220 - 250]:

ефективного розвитку економіки шляхом створення привабливого інвестиційного клімату, проведення антимонопольної та інфляційної політики, підтримки державних фінансів у бездефіцитному стані і таке інше;

економічної стабільності шляхом нівелювання галузевих диспропорцій, реструктуризації національної економіки, досягнення повної зайнятості населення, твердості національної валюти та рівноваги на зовнішньоекономічних ринках і т.п.;

соціальної справедливості шляхом ефективного розподілу доходів у суспільстві, введення і дотримання визнаних у світі соціальних стандартів життя та орієнтирів соціального розвитку відповідно до потреб українського суспільства.

Основними орієнтирами соціалізації при цьому мають стати показники $[12$, с. 84]:

1. Темпи зростання індексу цін, що не має перевищувати поріг 3-5\%; 
2. Темпи зростання грошової маси мають відповідати темпам зростання виробництва, але не перевищувати $3-5 \%$ на рік;

3. Рівень дефіциту державного бюджету має відповідати 3-5\% від ВВП;

4. Державний борг не має перевищувати $60 \%$ від ВВП;

5. Обсяг золотовалютних резервів має складати $8 \%$ від ВВП та бути достатнім для покриття витрат з імпорту товарів;

6. Для забезпечення розширеного відтворення рівень нагромадження у ВВП має складати не менше 10\%;

7. Відношення поточних платежів 3 обслуговування зовнішньоекономічного боргу не має перевищувати $20 \%$ річних доходів від експорту;

8. Рівень безробіття не має перевищувати 15-20\% відсотків від загальної кількості працездатного населення;

9. Розрив у доходах $20 \%$ найбагатших та 20\% найбідніших верств населення не має бути перевищений більш ніж у 12 разів.

Звідси метою даної статті $є$ обгрунтування системи відносин, що склалась у сучасній змішаній економіці, яка функціонує і розвивається під впливом історикоцивілізаційних, технологічних, соціальноекономічних світових та внутрішніх політичних процесів, що відбуваються в Україні та розробка концепції соціалізації виробництва, виходячи із існуючих умов функціонування.

Виклад основного матеріалу дослідження. Для багатьох країн, у тому числі і України, характерним для змішаної економіки є визначення пріоритетів, тобто своєрідних орієнтирів. Причому ці орієнтири мають включати не лише національні пріоритети, але й інші сучасні особливості розвитку країни як політична нестабільність, часта зміна урядів, соціально-економічних програм, а значить і економічних пріоритетів; відсутності реформ, їх блокування, що має серйозні наслідки для подальшої соціалізації економіки.

Сучасна змішана економіка України грунтується на успадкованих від попереднього часу ендогенних і екзогенних чинниках, що характеризуються неефективним соціальним спрямуванням, нераціональною виробничою структурою та інфраструктурою; макро- та мікроекономічними дисба- лансами; повзучою і прихованою інфляцією та іншими явищами.

Основою реформування економіки $\epsilon$ регіональна диференціація, що потребує ухвалення цілого комплексу заходів для забезпечення макроекономічної стабільності, зростання ВВП і скорочення зовнішнього боргу. I цей напрям має залишатися незмінним, якщо Україна прагне увійти до європейського співтовариства.

Слід провести й найскладніші реформи на ринку праці і у трудових відносинах, а саме зміну ієрархії престижних професій i цінностей. Такі перебудови можуть забезпечити як успішність запроваджуваних в країні реформ, так i, з іншого боку, знижувати соціальний статус деяких професій і людей, що займають певні посади попри наявного високого доходу.

Важливою складовою виступає й збалансованість державного бюджету, проведення вдалої податкової та трансфертної політики держави. За таких умов проблемою $є$ державне регулювання цін. Проте практика інших країн показує [3, с. 11], що з точки зору об'єктивності, саме цінове регулювання має вирішувати соціальні питання, але втручання держави в сферу попиту і пропозиції насправді нічого не дає, бо існуючий дисбаланс краще за все регулюють закони ринку, рівень розвитку вітчизняного виробництво та обсяги імпорту продукції.

Не дає певного ефекту і регулювання доходів населення з боку держави в умовах змішаної економіки, бо ринкові механізми надають рівні можливості вибору (місця діяльності, доступ до товарів та послуг, житла, дозвілля і т.п.), а значить й доходи працюючих повинні бути відповідними їх здібностям, професії, кваліфікації тощо. А якщо ринок не забезпечує таких можливостей, то тоді втручання держави має спрямовуватись на запровадження таких механізмів та активізацію їх соціальної відповідальності.

У авторських баченнях соціальної відповідальності вже неодноразово [13] підкреслювалось, що не може існувати ніяких загально прийнятих стандартів соціальної відповідальності, бо відмінності у інституціональних основах держав, специфічність основ розвитку економіки країни, кожного регіону, галузі, стан розвитку суспільства, рівень трансформації соціальної свідомості та сприйняття демократичних цінностей населенням, їх культурні особливості [14, с. 194 - 197] і таке інше - не сприяють створенню типових моделей щодо закріплення виконання суспільно значимих функцій за 
державою чи за бізнесом. Тому переважно в Україні існує соціальне інвестування [15], спонсорство, меценатство, благодійність, рух волонтерства і т.П., котрі формують особливі види морально-етичної, правової відповідальності та можуть застосовуватися кожний окремо або у певному поєднанні.

Сучасні глобалізаційні виклики актуалізують та орієнтують суспільство на вирішення проблематики етичних взаємовідносин, збереження життя, підтримки його добробуту та якості, самореалізації та самоорганізації кожного члена суспільства. Тобто, мова йде про розвиток різноманітних сфер соціуму та про міждисциплінарний аспект соціалізації змішаної економіки. В цих умовах слід звернути увагу на рівень синергійності суспільства, що залежить від ступеню запровадження принципів соціальної справедливості, задоволення колективних та індивідуальних потреб та форм взаємодії суспільства. Сучасні суспільства переважно відносять до суспільств зі змішаною синергією [14, с. 223, 224], що ма- ють інституції, які формують культуру довіри, як високу синергію, що виявляється у щедрості, надійності, доброзичливості. А значить сучасну змішану економіку можна називати економікою довіри. Проте існують і інші протилежні форми господарювання, в умовах обмеження будь-яких ресурсів, що породжують низьку синергійність та недовіру у суспільстві. Але наявність таких негативів суперечить принципам соціальної справедливості й відповідальності. Тому змішана економіка має закладати основи соціальності у самому високому іiі сприйнятті суспільством.

Соціалізація - це процес формування соціальних якостей особистості, завдяки яким вона адаптується до суспільства та впливає на рівень розвитку усіх сфер його діяльності, у тому числі економічну [16, с. 54-63].

У табл. 1 наведено сучасні загальні цінності українського суспільства та їх характеристика .

Т а б ли ц я 1

Характеристика сучасних загальних цінностей суспільства

\begin{tabular}{|c|c|}
\hline Перелік цінностей & Характеристика змін \\
\hline 1. Виробництво товарів. & $\begin{array}{l}\text { 1. Перехід від орієнтації на певні споживчі характерис- } \\
\text { тики речей, на виробництво екологічно безпечних това- } \\
\text { рів, що відповідають вимогам світової спільноти }\end{array}$ \\
\hline $\begin{array}{l}\text { 2. Орієнтація на приватну власність та } \\
\text { право власника вільно розпоряджатись } \\
\text { результатами своєї діяльності. }\end{array}$ & $\begin{array}{l}\text { 2. Перехід від державної власності до роздержавлення } \\
\text { та визнання приватного капіталу та власності. Закріп- } \\
\text { лення цього визнання у законодавчій базі, економічній } \\
\text { культурі та свідомості населення. }\end{array}$ \\
\hline $\begin{array}{l}\text { 3. Самостійна відповідальність за понесені } \\
\text { ризики від володіння власністю }\end{array}$ & $\begin{array}{l}\text { 3. Повна рівноправна відповідальність кожного грома- } \\
\text { дянина суспільства (або підприємця) за результати та } \\
\text { якість своєї діяльності. Ефективний розвиток соціаль- } \\
\text { но-економічних зв’язків та відносин, що запобігають } \\
\text { виникнення різного роду ризиків. }\end{array}$ \\
\hline $\begin{array}{l}\text { 4. Оцінювання результатів соціально- } \\
\text { економічної діяльності у вартісних показ- } \\
\text { никах. }\end{array}$ & $\begin{array}{l}\text { 4. Перехід від планових натуральних відсоткових пока- } \\
\text { зників до показників агрегованих, що характеризують } \\
\text { реальне соціально-економічне становище у суспільстві } \\
\text { за порівняльними показниками, що відповідають рівню } \\
\text { розвитку світового суспільства. }\end{array}$ \\
\hline $\begin{array}{l}\text { 5. Мотивація до ефективної праці, що ви- } \\
\text { будувана на принципах підвищення якості } \\
\text { робочої сили, використанні капіталу. }\end{array}$ & $\begin{array}{l}\text { 5. Процес стимулювання грунтуються на формуванні } \\
\text { індивідуальної та колективної (суспільної) зацікавлен- } \\
\text { сті у результатах праці. }\end{array}$ \\
\hline $\begin{array}{l}\text { 6. Стимулювання ініціативи до самоорга- } \\
\text { нізації, здатності до створення незалежних } \\
\text { об’єднань людей для захисту особистих та } \\
\text { суспільних інтересів. }\end{array}$ & $\begin{array}{l}\text { 6. Виховання патріотів суспільства, спроможних боро- } \\
\text { тися } 3 \text { корупцією, лобізмом особистих інтересів керую- } \\
\text { чої верхівки суспільства. }\end{array}$ \\
\hline
\end{tabular}

Джерело: розроблено автором на підставі [16, с. 56] 
Саме в цьому аспекті міститься відповідь на питання про якості, які має реалізовувати соціалізація сучасного суспільства:

по-перше, будь-яка соціалізація має бути заснована на економічному історикокультурному досвіді людства, у тому числі своєї країни;по-друге, має відповідати економічним і соціальним потребам суспільства, що корелюється 3 вимогами функціонуючої економічної системи в країні;

по-третє, мати прагнення до індивідуального задоволення, завдяки досягнення колективних орієнтирів, приналежності людини до окремої соціальної групи;

по-четверте, основними агентами соціалізації мають бути сім'я (родинні зв'язки), заклади освіти, котрі формують необхідні навички, компетенції, ставлення до суспільних й індивідуальних цінностей, заохочує та мотивує до гармонійного розвитку, підтримки існуючих традицій та

створення свого особливого громадянина суспільства;

по-п'яте, різні економічні системи стимулюють і створюють свої особливі властивості індивіда. Зміна соціальних умов викликає зміну економічних цінностей i, відповідно, - зміну орієнтації образу життя особистості.

Отже в основі сучасної концепція формування змішаної економіки має знаходитись економічно орієнтована людина, котра озброєна певними економічними і фінансовими знаннями, індивідуальними й колективними навичками, культурою спілкування, прагненнями досягти максимальної корисності визнання українського суспільства світовим, що дозволить їй правильно зорієнтуватись в економічному просторі та проявити себе в процесі його соціалізації. Звідси, концепцію змішаної економіки можна представити у вигляді двох макро- i мікросистем (рис. 1).

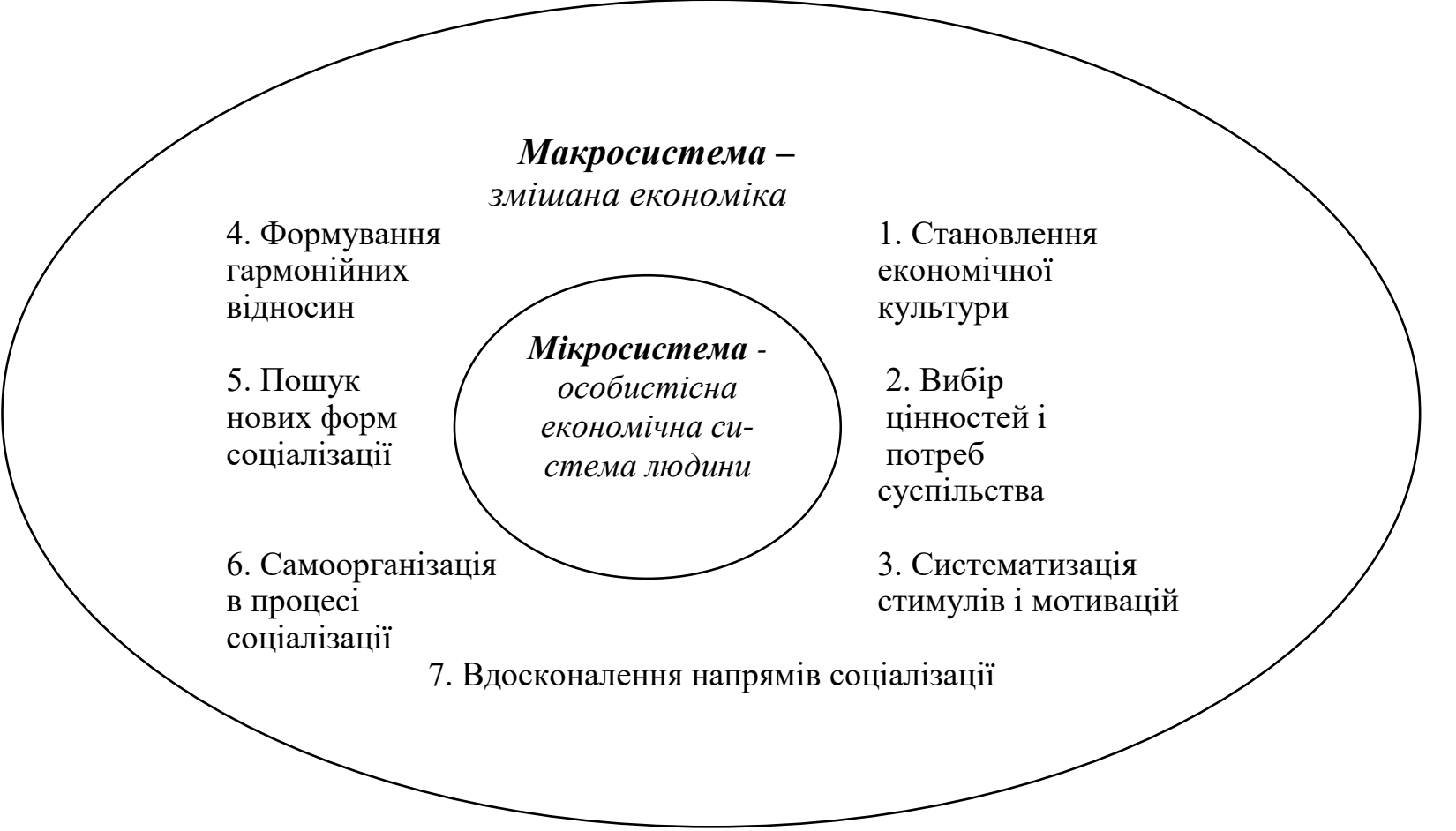

Рис. 1 Концепція змішаної економіки в умовах функціональної соціалізації виробництва Джерело: розроблено автором

Представлена концепція узагальнює процес соціалізації змішаної економіки, виходячи 3 тих соціально-економічних тенденцій та внутрішніх політичних процесів, що відбуваються в Україні та дозволяє спрямувати увагу на забезпечення особис- тісних інтересів кожної людини - громадянина суспільства та безпосереднього учасника будь-якого виробничого процесу.

Висновки та перспективи подальших досліджень: За результатами проведеного дослідження можна констатувати: 
1. В основі концепції формування змішаної економіки знаходяться відповідальність держави стосовно забезпечення прозорого законодавства, рівність всіх економічних суб'єктів перед законом, що дозволить забезпечити зростання економічного потенціалу країни, життєвого рівня населення та кожного громадянина суспільства.

2. Соціалізація та іiї напрями є розвитку $є$ основою міждисциплінарного дослідження більшості суспільно-гуманітарних наук, що підкреслюють необхідність і доцільність розгляду, гармонізації взаємовідносин між людиною (котра $\epsilon$ головного об'єктом дослідження) та суспільством.

3. Доведено вплив новітніх світових аспектів соціально-економічних відносин на напрями соціалізації, що відбивається у змісті напрямів соціалізації та її характері.

4. Динаміка соціалізації залежить від реалізації і задоволенні інтересів і потреб суспільства, можливостей запровадження вибраних цінностей в економіку та сприйняття цих орієнтирів українськім соціумом та кожним окремим громадянин.

Подальші дослідження будуть спрямовані на визначення чинників, що можуть прискорювати, чи навпаки - гальмувати процеси соціалізації змішаної економіки.

\section{Література}

1. Коваленко М.М. Порівняльні економічні системи й публічне адміністрування / М. М. Коваленко, О. С.Лєсная. - Харків: Вид-во: ХарРІ НАДУ «Магістр», 2016. $176 \mathrm{c}$.

2. Економічна енциклопедія: У трьох томах. Т.1. / Редкол..... С.В. Мочерний (відп. ред.) та ін. - К.: Видавничий центр «Академія», 2000. - 864 с.

3. Шибаєва K. I. Змішана економіка: теорія і сучасна дійсність: автореф. дис. на здобуття наук. ступеня канд. екон. наук за спец. 08.00.01 - економічна теорія та історія економічної думки / К.І. Шибаєва. Донецьк: Донецький національний університет, 2011. - 16 c.

4. Kramar $O$. The poorest country in the Europe / O. Kramar // The Ukranian Week. №4 (134), April 2019. - P. 22 -25.
5. Vikhrov M. "Can't get no satisfaction..." / M. Vikhrov // The Ukranian Week. №6 (132), February 2019. - P. 18 - 19.

6. Україна 2030: Доктрина збалансованого розвитку. - Львів: Кальварія, 2017. $168 \mathrm{c}$.

7. Kramar $O$. "Is this the end of the era of povetry"? / O. Kramar // The Ukranian Week. - №4 (136), June 2019. - P. 22 -25.

8. Kramar $O$. Go West, young trader / O. Kramar // The Ukranian Week. - №5 (135), May 2019. - P. 26 - 28.

9. Kramar $O$. System, recovered. Now back it up / O. Kramar // The Ukranian Week. - №10 (128), October 2018. - P. 30 - 33.

10. Зюзь Д. В. Сутність та чинники розвитку економічної системи / Зюзь Д.В. // Державне будівництво. - №2, 2016. Режим доступу: www.kbupa.kharkov.ua

11. Самоорганізація підприємств: тенденції соціалізації економіки: монографія / Т.В. Калінеску, Г.С.Ліхоносова, Г.О. Надьон, С.П. Кілінкаров. - Луганськ: вид-во СНУ ім. В. Даля, 2012. - 396 с.

12. Штулер I. Ю. Історичне та економічне підгрунтя вибору моделі «випереджаючого розвитку» національною економічною системою / І.Ю. Штулер // Науковий вісник Мукачівського державного університету. Серія Економіка. Випуск №1(5), 2016. - C. $81-87$.

13. Калінеску T. В. Соціальна відповідальність та розвиток діалогу в українському суспільстві / Т.В. Калінеску // Постулати минулого та перспективи реалізації бюджетно-податкової політики: монографія / [Колектив авторів], за наук. ред. Т.В. Калінеску. - Сєвєродонецьк: Вид-во СНУ ім. В. Даля, 2015. - С. $141-150$.

14. Соціально-філософські аспекти розвитку економіки, управління та освіти в умовах формування сучасного суспільства: монографія / За ред. М.П. Іщенка, Н.М. Пантелеєвої, І.І. Руденка. - Черкаси: вид-во ПП Чабанеко Ю.А., 2017. -473 с.

15. Калінеску T. В. Соціальне інвестування та відповідальність підприємств: монографія / Т.В. Калінеску, О.О. Зеленко, М.O. Наталенко. - Луганськ: Вид-во СНУ ім. В. Даля, 2013. - 292 с.

16. Соціально-психологічні закономірності становлення економічної культури 
молоді: монографія / В.В. Москаленко, О.В. Лавренко, Н.М. Дембицька, І.К. Зубіашвілі [та ін.]; за ред. В.В. Москаленко. - К.: Педагогічна думка, 2015. -406 с.

\section{Reference}

1. Kovalenko, M.M. \& Lesnaia, M.M. (2016). The comparative economic systems and public administration. Kharkiv: Printed of KharRI NASM "Master's Degree", 176.

2. Economic encyclopaedia: In three volumes. Volume 1. (2000). By editors S.V. Mocherny and other - Kyiv: Publishing center "Academy", 864.

3. Shibaeva, K.I. (2011). Mixed economy: theory and modern reality: autoreferat of candidat's degree for specialty 08.00 .01 - economic theory and history of economic opinion. Donetsk: Donetsk national university, 16.

4. Kramar, O. (2019). The poorest country in the Europe. The Ukranian Week, 4 (134), 22 -25.

5. Vikhrov, M. (2019). "Can't get no satisfaction..." The Ukranian Week, 6 (132), 18 19.

6. Ukraine is 2030: Doctrine of the balanced development (2017). Lviv: Kalvaria, 168.

7. Kramar, O. (2019). "Is this the end of the era of povetry"? The Ukranian Week, 4 (136), June 2019. - P. 22 -25.

8.Kramar, O. (2019). Go West, young trader. The Ukranian Week, 5 (135), 26 - 28.

9.Kramar, O.(2018). System, recovered. Now back it up. The Ukranian Week, 10 (128), $30-33$.

10. Zuz, D.V (2016). Essence and factors of the economic system development. State

Стаття надійшла

до редакції : 01.09.2019 p. building, 2. Electronic source (Web publication). Retrieved from: www.kbupa.kharkov.ua

11. Calinescu, T.V. \& Likhonosova, G.S. \& Nadion, G.O. \& Kilinkarov, S.P. (2012). Selforganization of enterprises: tendencies of economy socialization: monograph. Luhansk: Printed Volodymyr Dahl East Ukrainian National University, 396.

12. Shtuler, I.Y. (2016). Historical and economic basis of choice the model of "passing ahead development" by the national economic system. Scientific Bulletin of Mukachevo state university. Series of Economy. Producing 1(5), 81 - 87.

13. Calinescu, T.V. (2015). Social responsibility and development of dialog in Ukrainian society. In a book: Postulates of the past and prospect of realization of budgetarytax policy: monograph. By editor T.V. Calinescu. Severodonetsk: Printed Volodymyr Dahl East Ukrainian National University, 141 - 150.

14. Social and philosophical aspects of economy, management and education development in the conditions of forming the modern society: monograph (2017). By editors M.P. Istshenko, N.M. Panteleeva, I.I. Rudenko. Tcherkasy: Printed of PB Chabanenko Y.A., 473.

15. Calinescu, T.V. \& Zelenko, O.O. \& Natalenko, M.O. (2013). Social investing and responsibility of enterprises: monograph. Severodonetsk: Printed Volodymyr Dahl East Ukrainian National University, 292.

16. Moskalenko, V.V. \& Lavrenko, O.I. \& Dembytska N.M. \&. Zubiashvili, I.K. \& [other] (2015). Social and psychological conformities of becoming the economic culture of young people: monograph. By editor V.V. Moskalenko. Kyiv: Pedagogical idea, 406.

Стаття прийнята

до друку: 27.09.2019 p.

\section{Бібліографічний опис для цитування :}

Калінеску Т. В. Концепція формування змішаної економіки в умовах функціональної соціалізації виробництва / Т. В. Калінеску // Часопис економічних реформ. - 2019. № 3 (35). - C. 15-23. 